\title{
THE IMPORTANCE OF EDUCATION TO UNDERSTAND TRADE FACILITATION AGREEMENT (TFA)
}

\section{Pentingnya Pendidikan untuk Memahami Perjanjian Fasilitasi Perdagangan}

\author{
Kumara Jati ${ }^{1}$, Arie Mardiansyah ${ }^{2}$, Muhammad Fawaiq ${ }^{3}$, Steven Raja Ingot ${ }^{4}$ \\ ${ }^{1}$ Ispahani Center, Nungambakkam High Road, Chennai-India 600034 \\ Indonesian Trade Promotion Center-Chennai, kumara_jati@yahoo.com \\ 1,2,3,4 JI.M.I.RidwanRais No.5, Gambir, Jakarta10110 \\ Trade Analysis and Development Agency, Ministry of Trade
}

\begin{abstract}
:
Education is a very essential factor in human life, because if someone get the certain knowledge then they will be able to make a better decision, self empowerment and aware of rules and regulations in the world. Two of the important regulations related to international trade are coming from The World Trade Organization (WTO) and Trade Facilitation Agreement (TFA). Indonesia has ratified the Trade Facilitation Agreement (TFA) on 5 December 2017. The new agreement related to WTO and TFA needed to be learnt and teach with a good Education Model. The most important role of skill policies and education in globalization era is its role in facilitating the international flow of ideas. This research can fill the gap to make an Educational Model of TFA based on Non-Juridical and Juridical Education. Both factors become very important things because the stakeholders can use this model to more quickly and easily understand the substance of TFA, so that Indonesia can fully implement the TFA commitments in the digital database WTO in the year 2022.
\end{abstract}

Keywords: Importance of Education, Trade Facilitation Agreement (FTA), Descriptive Analysis, Normative Juridical Analysis, Education Model of TFA

\begin{abstract}
ABSTRAK:
Pendidikan adalah faktor penting dan nyata dalam kehidupan manusia, karena jika seseorang medapatkan pengetahuan tertentu maka mereka akan dapat membuat keputusan yang lebih baik, pemberdayaan diri dan sadar akan peraturan dan regulasi yang ada di dunia ini. Dua peraturan penting terkait dengan perdagangan internasional berasal dari Organisasi Perdagangan Dunia (WTO) dan Perjanjian Fasilitasi Perdagangan (FTA) pada 5 Desember 2017. Perjanjian baru terkait WTO dan TFA perlu dipelajari dan diajarkan dengan Model Pendidikan yang baik. Peran paling penting dari kebijakan keterampilan dan Pendidikan di era globalisasi adalah perannya dalam memfasilitasi aliran gagasan internasional. Penelitian ini dapat mengisi kekosongan untuk membuat Model Pendidikan TFA berdasarkan Pendidikan Non-Yuridis dan Yuridis. Kedua faktor tersebut menjadi hal yang sangat penting karena pemangku kepentingan dapat menggunakan model ini untuk lebih cepat dan mudah memahami substansi TFA, sehingga Indonesia dapat sepenuhnya mengimplementasikan komitmen TFA dalam basis data digital WTO pada tahun 2022.
\end{abstract}

Kata kunci : Pentingnya Pendidikan, Perjanjian Fasilitasi Perdagangan, Analisis Deskriptif, Analisis Yuridis Normatif, Model Pendidikan TFA 


\section{INTRODUCTION}

Human Resources (HR) are the main subject in building a better country. The quality of HR can be improved with significant and valuable contribution from education. The government must have a commitment to be serious in favor of improving the quality of education in order to become a more advanced nation (Muhardi, 2004).

According to (NCERT, 2014), education in a narrow sense is a purposeful activity, deliberately planned for the optimum development of an individual's potentials, and education in a broader meaning is a life long process, where all the experiences, knowledge and wisdom that an individual acquires at different stages of one's life through different channels (formally, informally and incidentally). Education is a very important factor in human life, because if someone get the certain knowledge then they will be able to make a better decision, self empowerment and aware of rules and regulations in the world (Bhat, 2014). Two of the important regulations related to international trade are coming from The World Trade Organization (WTO) and Trade Facilitation Agreement (TFA).

The World Trade Organization (WTO) is the only global international organization dealing with the rules of trade between nations. In December 2013, Indonesia has hosted the World Trade Organization (WTO) Ministerial Conference held in Bali. In the implementation of the 2013 WTO Ministerial Conference, it was agreed "Bali Package". The Bali Package is a continuation of the wider Doha Round negotiations. Bali Package consists of a number of agreements that are expected to be a driver of the progress of all member countries, especially developing countries and poor countries. As the first major agreement among WTO members, Bali Package aims to streamline trade, allowing developing countries more options to provide food security and increase trade for poor countries. The outcome of the agreement is poured into three packages. The three packages are
Agreement on Agriculture, package for Least Developed Countries (LDCs), and Trade Facilitation Agreements (TFA).

As the largest WTO reform since its founding, the Agreement on Trade Facilitation was finally agreed upon after years of negotiations. The issue of trade facilitation has, in effect, already been discussed since year 1996. This discussion was conducted in the 1996 Ministerial Declaration in Singapore. The results of the Declaration laid the foundation for the upcoming of the Agreement on Trade Facilitation. In addition, the WTO Council on Trade in Goods considered it important to clarify Article V, VII, X of the 1994 General Agreement on Tariffs and Trade (GATT).

Indonesia has ratified the Trade Facilitation Agreement (TFA) on 5 December 2017. There are three categorizations (A, B, C) when implementing TFA in their respective countries whereas $B$ and $C$ category is a facility only given to developing and LDCs countries for them to choose. In Digital Database TFA World Trade Organization (WTO), status of TFA notification in Indonesia as of 2019 is: $88.7 \%$ in category $\mathrm{A}$ and $11.3 \%$ in category $\mathrm{B}$. This number in category $\mathrm{A}$ still lower compared to neighboring countries such as Malaysia $(94.1 \%)$, Philippines (93.3\%) and Thailand (93\%).

To the best of our knowledge, not many research exists related to the importance of education to understand the Trade Facilitation Agreement (FTA) using descriptive and normative juridical analysis. There is an opportunity to fill the gap of research so that this paper can contribute as a reference to relevant authorities and in a research literature. Based on the explanation above, the purpose of this paper is to analyze and examine the educational contribution to understanding Trade Facilitation Agreement (TFA) and to make an education model of TFA.

\section{LITERATURE REVIEW}

According to OECD (2018), education can make the difference for 
people to embrace challenges in the face of an increasingly volatile, uncertain, complex and ambiguous world. The sector of education is subject to globalization (Sauvé, 2002). This has led to different point of view related to the education sector role in nation building and its position in international trade (Velde, 2005).

Also, according to WTO (2017), quality of education affects the individual labor market outcomes and overall national economic performance. The new agreement related to WTO and TFA needed to be learnt and teach with a good education model. The most important role of skill policies and education in globalization era is its role in facilitating the international flow of ideas (WTO, 2011).

Furthermore, Sitorus, Priyono and Paulus (2016) examine Implementation of National Treatment Principle for Philippines-Taxes on Distilled Spirits Disputes. They found that the panel WTO Appeals Body uses interpretation and explanation in analyzing the WTO disputes. Many terms in WTO, several chapters that require the interpretation of the law so that the explanation of these terms is important as a permanent legal basis for WTO members.

Prabowo (2013) focus on legal review of international rules about liberalizing service trade through the framework WTO agreements and framework of the ASEAN agreement. He found that GATS, as a basic rule of international trade in service sector, established the obligations applicable to all those measures affecting international trade. Each member country provides commitment applies to the service sector and the sub-sector of services that are flattened on the Schedule of Commitments. The basic rules of trade law in international service sector attached in Annex 1b GATS. This agreement specifically seeks to improve efficiency and the competitive level of ASEAN members as service providers, in particular eliminating trade restrictions on services among ASEAN members, by extending the level and scope of liberalization beyond those already in GATS.

\section{RESEARCH METHODOLOGY}

The Descriptive Analysis approach is used to compare some of the domestic regulations that related to the Trade Facilitation Agreement (TFA). This approach presents the qualitative data table such as: regularity alignment, regularity substance and its relevance to the simplification program for Trade Facilitation Agreement (TFA). The Normative Juridical Analysis is a model that directly examines the legislation and implementation approach. This model focuses on reviewing laws and regulations in domestic area related to the Trade Facilitation Agreement (TFA). Then the implementation approach, focus on reviewing the practice of laws and regulations in Indonesia.

Similar research papers used combination of normative juridical analysis, policy analysis other methodologies in Indonesia (Ridha, 2015; Utami and Ridha, 2015; Laksani, 2016; Jati and Wicaksena, 2017). Some part of the analysis in these papers used normative juridical method where the paper is focused to elaborate the use of regulation and norms in positive law. The Juridical analysis especially related to the World Trade Organization (WTO) or other international institutions, agreements and domestic regulations.

Yusuf (2015) analyzed the implementation of WTO principles in Law No.7 of 2014 on Trade. One of the universal principles known in WTO is the non-discrimination, where this principle has been implemented in the trade law. Then, on the harmonization of the legal regulations in the field of trade in order to face global competition is needed for Indonesia. Furthermore, Indonesia is one of the countries that embrace the democratic economic system, while Indonesia as one of the member WTO cannot be separated from the rules in WTO itself. So both must be harmonized to avoid conflicts that may occur among WTO countries, especially in the field of trade. 
Data Retrieval and Implementation Time of Research

This research paper required data from secondary and primary resources. The secondary data are obtained from articles, books, journals, relevant authorities, and other sources that have a good relation to the database digital WTO, Trade Facilitation Agreement and Normative Juridical Analysis. The primary data are obtained from government, business entities and other private institutions that have relation to the WTO during Focus Group Discussion (FGD) and observation in Trade Facilitation Agreement (FTA) conference in Jakarta in the year 2018. The results of primary data collection are confirmed by expert group related to Trade Facilitation Agreement (TFA) and WTO.

\section{Stages of Research Framework}

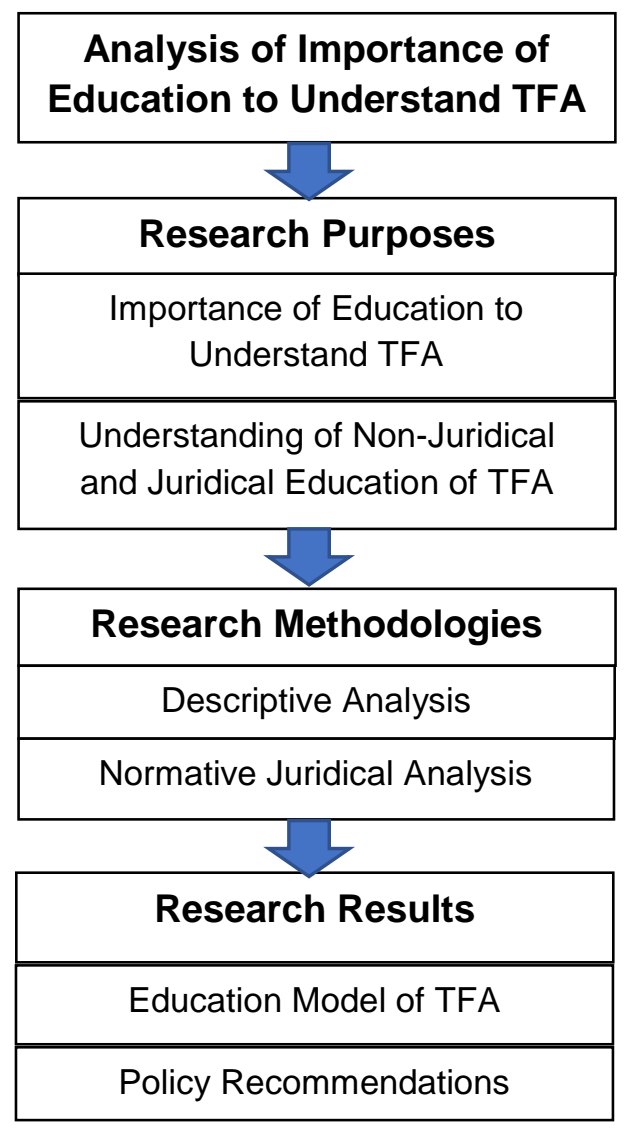

Figure 1. Stages of Research Framework

Source: Researchers Concept (2019)
Figure 1 shows the research framework stages. There are two research purposes discussed in this research, namely importance of education to understand TFA and understanding of Non-juridical and juridical education of TFA. This research uses two methodologies for obtaining research purposes i.e. with descriptive analysis and normative juridical analysis. At the end of the research, will be described research results which are education model of TFA and policy recommendations to the relevant authorities.

\section{RESULT AND DISCUSSION}

\section{Descriptive Analysis of Trade Facilitation}

There are several definitions of Trade Facilitation. According to WTO (1998), trade facilitation is the simplification and harmonization of activities, practices, and formalities involved in collecting, presenting, communications and processing data required for the movements of goods in international trade. This definition only covers trade in goods that is explained in GATT article $\mathrm{V}$ (freedom of transit), GATT article VIII (fees and charges), GATT article $X$ (publications and transparency).

\section{Table 1. Definition of Trade Facilitation}
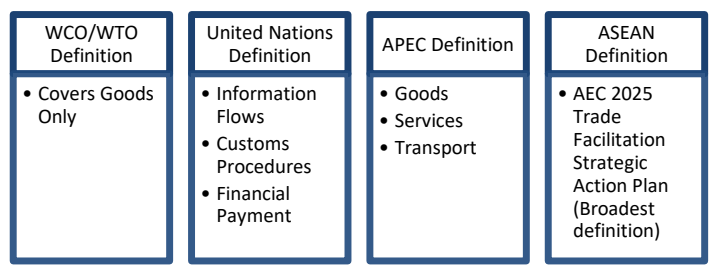

Source: TPSA (2018), WTO (1998), modified

The definition of Trade Facilitation according to United Nations is much 
broader because covers: customs procedures, flows of information and financial payment. Trade facilitation is the simplification, standardization and harmonization of procedures and associated information flows required to move goods from seller to buyer and to make payment.

There are two definitions of Trade Facilitation according to Asia-Pacific Economic Cooperation (APEC) organization. First defined in 1999, trade facilitation is the use of technologies and techniques which will help members to build up expertise, reduce costs and lead to better movement of goods and services. The second definition in 2002, trade facilitation in 2002, trade facilitation is the simplification, harmonization, use of new technologies, and other measures to address procedural and administrative impediments to trade.

The broadest definition of trade facilitation has come from ASEAN (2016). The trade facilitation definition goes beyond customs procedures and process, including standards and conformance. It is adopted in The ASEAN Trade Facilitation Framework (ATFF) in 2016 with the aim to consolidating ASEAN's trade facilitation obligations and commitments in the various ASEAN documents such as the ASEAN Vision 2025: Forging Ahead Together, ASEAN Economic Blueprint 2025; ASEAN Trade in Goods Agreement 2010". These definitions are very useful to make Trade Facilitation theory to be applied in a more comprehensive way in Indonesia.

Indonesia is very attractive to investors because it has a huge population (the 4th most populous country in the world) and domestic consumption base which is the platform for the current investment potential and economic growth (KPMG, 2015). Economy of Indonesia is still believed to experience a steady and positive growth supported by the commitment of Indonesian government's to accelerate the ease of business as outlined in Peraturan Presiden Nomor 91 Tahun 2017 tentang Percepatan Pelaksanaan
Berusaha (Republik Indonesia, 2017) to arrange the Online Single Submission system; and the implementation of the Economic Policy Package (Investindonesia, 2018a).

There are two important factors to make sure that investors want to bring their fund to specific countries: (1). Investors need to export and import in an efficient and effective way and at minimal cost to engage with Global Value Chains (GVCs), (2) ease of doing business indicators is one of the main reasons for investors to put their fund money abroad. Ease of business rank in Indonesia increased from 91 in 2017 become 72 in 2018, it is second highest progress compared to others ASEAN countries, and the highest compared to previous years (year 2013: rank 129, 2014 rank: 120, 2015: rank 114, 2016: rank 108).

Table 2. Ease of Doing Business (EDB) Rank in ASEAN Countries

\begin{tabular}{|l|l|l|l|l|}
\hline No & Country & $\begin{array}{l}\text { DB } \\
\text { Rank } \\
\mathbf{2 0 1 7}\end{array}$ & $\begin{array}{l}\text { DB } \\
\text { Rank } \\
\mathbf{2 0 1 8}\end{array}$ & Status \\
\hline 1 & Indonesia & 91 & 72 & Better \\
\hline 2 & Singapore & 2 & 2 & Stable \\
\hline 3 & Malaysia & 23 & 24 & Worst \\
\hline 4 & Thailand & 46 & 26 & Better \\
\hline 5 & Brunei & 72 & 56 & Better \\
\hline 6 & Vietnam & 82 & 68 & Better \\
\hline 7 & Philippines & 99 & 113 & Worst \\
\hline 8. & Lao PDR & 139 & 141 & Worst \\
\hline 9. & India & 100 & 77 & Better \\
\hline
\end{tabular}

Source: World Bank, (2018), modified

Exist a space to increase the rank of doing business for Indonesia in the near future. Related to ease of trading across borders, Indonesia in the rank 112. This rank is lower compared to Philippines in 99, China in 97, Vietnam in 94, Malaysia in 61, Thailand in 57, Singapore in 42 and Hong Kong in 31. This trading across borders rank, measures the time and cost to export the product of comparative advantage and import auto parts (World Bank, 2018). Indicators of Trading across borders have been considered as a tool to measure the outcomes of government trade facilitation works (WCOOMD, 2018). 
The components of Trading across Borders are time to export (25\%), cost to export (25\%), time to import (25\%) and cost to import (25\%) (WCOOMD, 2018). In terms of Cost of Export (USD) rank, Indonesia is USD 391. This number is cheaper compared to China (USD 568), and Philippines (USD 509). Although Indonesian rank is still more expensive compared to Singapore (USD 372), Malaysia (USD 366), Vietnam (USD 339), Thailand (USD 320), and Hong Kong (USD 57). Different story when it comes to time to export (hours) rank, Indonesia (114 hours) is still relatively lower compared to Vietnam (105 hours), Thailand (62 hours), China (57 hours), Malaysia (55 hours), Singapore (12 hours), and Hong Kong (3 hours).

Trade Facilitation Agreement structure divided into four parts: Preamble, Section I - Substantive Provisions, Section II - Special and Differential Treatment, and Section III Institutional Arrangements and Final Provisions. Preambles explain the TFA objectives: (1) identify the Least Developed Countries' particular needs, (2) identify the requirement for cooperation on customs compliance and trade facilitation, (3) clarify and improve GATT Article V, VIII and X.

Moreover, there are four important scopes in the Section I - Substantive Provisions: (1) article 1-5 (transparency), (2)article 6-10 (fees and formalities), (3) article 11 (transit), and (4) article 12 (customs cooperation). In the section II, there are three categories: (A) implementation upon entry into force, (B) transition period, (C) transition period and financial and/or technical assistance. Indonesia has notified the TFA: $88.7 \%$ in category $A$ and $11.3 \%$ in category $B$. This means that no technical assistance needed for Indonesia.

Furthermore, there are two important parts in TFA section III Institutional arrangements and final provisions which are: (1) Multilateral (Article 23.1 WTO Trade Facilitation Committee), and (2) National (Article 23.2 National Trade Facilitation
Committee/NTFC). The NTFC is a multiagency permanent platform where private and public stakeholders coordinate and discuss trade facilitation measures at a national level.

In the future, Indonesia should establish the NTFC that combined from four different entities: (1) government (regulators and policymakers), (2) private sectors (services providers, trade service users and customs brokers), (3) civil society (NGOs, trade unions and consumer associations), (4) partners of development (partner economies and international institutions). According to UNCTAD (2017), external motivations $(56 \%)$ give more rationale for the establishment of NTFC compared to the internal motivations (44\%). One of the biggest difficulties in domestic to accelerate the NTFC is coordination across stakeholders (37\%).

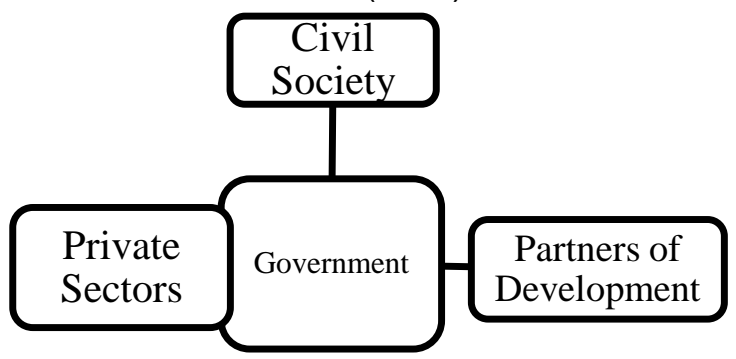

\section{Figure 2. Organization Concept of NTFC}

Source: TPSA (2018), modified

Based on the experienced of other countries that already established NTFC, there are average combinations of government and private membership that can be given input to the development of organization concept of NTFC in Indonesia. Sectors that involved in governments are: transport (22\%), trade and economy (21\%), agriculture (15\%), customs (11\%), and others $(31 \%)$. Then, private sectors average combinations are: traders and associations (58\%), transporters $(30 \%)$, and others (12\%).

Cooperation between the Coordinating Ministry for Economic Affairs, Ministry of Trade, Indonesian Chamber of Commerce and Industry and the World Bank was established in 
order to support export, import and intratrade in Indonesia. The government's effort to encourage trade facilitation implementation, such as the improvement of Indonesia National Single Window (INSW), ASEAN Single Window (ASW), and the development of the National Logistics Blueprint, are supported by the World Bank. The World Bank's support includes the following items:

i.) Provide recommendations on best practices in regulating institutional and processing of trade support policy reforms.

ii.) Risk management training for government agencies involved in the National Single Window.

iii.) Strengthen the institutional capacity with good training and education from the Ministry of Trade officials in order to make policy decisions on the basis of sufficient information.

iv.) Support the capacity building of the Ministry of Trade to better understand the nature and impact of Non-Tariff Measures (NTMs).

v.) Strengthen the capacity of government agencies and private sector organizations to engage in dialogue on trade in services and relations.

\section{Normative Juridical Analysis of Trade Facilitation Agreement (TFA) \\ TFA entered into force on} February 22, 2017. It applies to all APEC Economies that have accepted and ratified it. Each economies of APEC that accepts the TFA after its entry into force, it will take effect upon acceptance, in accordance with Article $\mathrm{X}: 3$ of the Marrakesh Agreement Establishing the World Trade Organization (WTO). Total there are 24 articles and 1 annex. In this normative juridical analysis section, only focus on the articles that important for the education of relevant stakeholders in Indonesia.

Article 1 TFA: Publication and Availability of Information

Section I, Article 1 TFA is one of the most important articles in TFA. This can be seen that United States proposed project to Asia-Pacific Economic Cooperation (APEC) Secretariat related to "Capacity Building and Technical Assistance to Implement Programs related to WTO Trade Facilitation Agreement (TFA) Article 1: Publication and Availability of Information".

The provisions of Article 1 TFA regarding publication is a follow up of Article $X$ of GATT on Publication and Administration of Trade Regulations. In Indonesia, the information referred to in Article 1 paragraph (1) TFA is information on export, import, transit, procedure, tariff, tax, application, legislation, administrative and other procedures included in the category of public information according to Article 1 paragraph (2) and Article 9 paragraph (2) Act of The Republic of Indonesia Number 14 of 2008 on Public Information Openness (Republik Indonesia, 2008).

\section{Article 3 TFA: Advance Rulings}

In Indonesia, advance ruling is a letter of affirmation (ruling) on a transaction (general or specific issued by the Directorate General of Tax (Dirjen Pajak) to the taxpayer. As one important instrument, advance ruling plays a role to assist taxpayers in fulfillment of tax obligations correctly. Advance ruling is a letter about the tax treatment of a specific transaction that will be done or faced by the taxpayer. Advance ruling is granted before the taxpayer makes a transaction or prior to reporting the notice (Surat Pemberitahuan/SPT). The advance ruling will facilitate taxpayer in fulfilling and carrying out his own obligations and taxation rights.

\section{Article 4 TFA: Procedures for Appeal or Review \\ Section I, Article 4, Paragraph (5)} and (6) TFA emphasizes more on the transparency of the decision made. Based on the Article 3 of Undangundang No.28 Tahun 1999 tentang Penyelenggaraan Negara yang Bersih dan Bebas dari Korupsi, Kolusi dan Nepotisme (Republik Indonesia, 1999), 
this regulation shows that transparency must be based on in accordance with the general principles of state administration. The obligation to provide legal consideration in a court decision is also an obligation under Article 68A paragraph (1) of Undang-undang No.49 Tahun 2009 tentang Perubahan Kedua atas Undang-undang No.2 Tahun 1986 tentang Peradilan (Republik Indonesia, 2009).

Article 5 TFA: Other Measures to Enhance Impartiality, NonDiscrimination and Transparency

Section I, Article 5, TFA regulates Sanitary and Phytosanitary (SPS) Agreement. The SPS agreement shall implement the provisions of Article 20 Sub-Article b GATT. Prohibition or restriction of dangerous Trade of Goods and/or Services relating to the environment shall be regulated in Article 35 paragraph (1) Sub-Article d of UU No.7 tahun 2014 tentang Perdagangan. In Article 50, paragraph (2), Sub-Article c of Trade Law, the government also provides restrictions on the environment.

Article 6 TFA: Disciplines on Fees and Charges Imposed On or In Connection with Importation and Exportation and Penalties. The most relevant authorities in Indonesia related to Article 6 is Directorate General of Customs and Excise (Dirjen Bea dan Cukai). The function of implementations of Directorate General of Customs and Excise are (Arfin, 2016):

i.) Trade Facilitation is to provide trade facilities (such as increasing the smooth flow of goods and trade) so as to suppress the high cost economy which will ultimately create a conducive trading climate.

ii.) Industrial Assistance is to provide support to the domestic industry so as to have a competitive advantage in the international market.

iii.) Revenue Collector is to optimize state revenue through the acceptance of import duties and excise. iv.) Community Protector is protecting the public from the entry of prohibited or restricted goods that may interfere with health and safety and morality.

Article 8 TFA:
Cooperation
Inter-Agency Agency
borders requires interagency coordination. The border issue is also related to the development of border areas in order to improve trade facilities. In the context of trade, the relevant institutions or parties are the Directorate General of Customs and Excise under the Ministry of Finance, besides the Ministry of trade of Republic of Indonesia. Due to the relationship between countries, the coordination should also coordinate with the Ministry of Foreign Affairs. In addition, the coordination can also involve the Ministry of Transportation because of the facilities to run the cooperation will certainly be closely related to transportation problems such as ports or airports.

\section{Article 9 TFA: Movement of Goods Intended for Import Under Customs Control}

Regarding the effort to simplify the formalities and document requirements, Indonesia and ASEAN have made an Indonesia National Single Window (INSW) and ASEAN Single Window (ASW). On May 2018 (Republik Indonesia, 2018):

(i.) Presidential Regulation Number 10 Year 2008 concerning Use of Electronic Systems in the Framework of Indonesian National Single Window (INSW) as amended by Presidential Regulation Number 35 Year 2012 concerning Amendment to Presidential Number 10 Year 2008 concerning use of Electronic System within Framework of INSW is not accordance with national demands and global challenges. It is declared to be revoked and declared invalid or withdrawn.

(ii.) Presidential Regulation Number 76 Year 2014 concerning Indonesia 
National Single Window Portal Manager; declared to be revoked and declared invalid or withdrawn.

(iii.) Presidential Regulation Number 44 Year 2018 about Indonesia National Single Window (INSW) is created to maintain the continuity of the implementation of Indonesian Economy in order to be able to compete in the international data delivery system in the export and import process within INSW. The global strategic environmental changes demand increased transparency, consistency, and efficiency of export and import process flow of international trade activities and create an integrated environment in the process of expenditure of goods in line with international trade practices.

\section{Article 11 TFA: Freedom of Transit}

The laws and regulation related to the application of Freedom of Transit is Undang-undang No.17 Tahun 1985 tentang Pengesahan United Nations Convention on the Law of the Sea (Republik Indonesia, 1985). Under this Convention, the freedom of transit is governed in Chapter $X$ on the right of landlocked countries (e.g. Laos, Bhutan, and Nepal) to access to and from the sea and freedom of transit.

In general, there are no laws and regulations in Indonesia that are against the freedom of transit. However, there are some differences arrangement of the provisions of an archipelago nation such as Indonesia. This distinction lies in the main point of arrangement on archipelagic sea lane passage rights, stating that such trajectory is a continuous, direct and expeditious cross-sectional route or flight. If further notice is given by the United Nations Convention on the Law of the Sea on the subject of transit, there is a difference in the imposition of conditions for the exercise of both kinds of lanes for the foreign vessel.

\section{Article 12 TFA: Customs Cooperation \\ Based on the Article12, paragraph (1), the way to encourage compliance is}

by creating a conducive economic climate. In the case of international trade cooperation between countries is regulated in Undang-undang No.7 Tahun 2014 tentang Perdagangan in Chapter XIII on International Trade Cooperation. Such International Trade Cooperation may be conducted through international trade agreements. The procedures for international trade cooperation are described in Article 83 and Article 84 UU No.7 Tahun 2014 tentang Perdagangan.

\section{The Overview of the Education Model of TFA}

This research can fill the gap to make an educational model of TFA based on Non-Juridical and juridical education (see Figure 3). Juridical or legal education of TFA is the education and training of individuals in the theory, principles, or practices of law and regulations related to TFA. Although TFA is a legally binding international trade agreement, there are also nonlegal factors (Non-juridical education of TFA) that must be reviewed to get a better understanding the substance of TFA.

The education model of TFA can be divided into two categories, which are: (1) the non-juridical education of TFA, consist of: (a) non-legally binding concept; (b) organization concept of the National Trade Facilitation Committee (NTFC), (c) stakeholder experiences, knowledges and wisdom, (d) stakeholders implementation commitments of TFA; (2) juridical education of TFA, consist of: (a) legally binding regulations (international and domestic), (b) domestic regulation understanding (UU No.7 tentang Perdagangan \& Peraturan Presiden Nomor 44 Tahun 2018 tentang Indonesia National Single Window), (c) other regulations related to TFA. Both factors become very important things so that Indonesia can fully implement the TFA commitments in digital database WTO. Hopefully, the stakeholders can use this model to more quickly and easily understand the substance of TFA. 


\section{CONCLUSIONS}

Education is really important factor in human life, because if someone get the certain knowledge then they will be able to make a better decision, self empowerment and aware of rules and regulations in the world (Bhat, 2014). Two of the important regulations related to trade are coming from The World Trade Organization (WTO) and Trade Facilitation Agreement (TFA).

The World Trade Organization (WTO) is the only global international organization dealing with the rules of trade between nations. Then, trade facilitation (TF) is activities for simplify and harmonize, practices, and formalities that involve in collecting, presenting, communicating and processing data required for the movements of goods from seller to buyer in international trade. ASEAN has Trade Facilitation definition is the broadest because goes beyond customs procedures and process including standards and conformance. The definition of TF is very useful for implementing the concept in a more comprehensive way in Indonesia.

The organization concept of a National Trade Facilitation Committee (NTFC) is important to give a contribution for non-juridical education model of TFA. The sharing experiences, knowledges, and wisdom can be done between APEC economies so that private and public stakeholders can coordinate and discuss trade facilitation measures at a national level. Indonesia should establish this organization concept of TFA from the combination of government, private sectors, civil society and partners of development. Coordinating Ministry for Economic Affairs in Indonesia will coordinate all the stakeholder and maintain the organization of the NTFC. This NTFC organization can help the Indonesia's stakeholder implementation commitments of TFA and to streamline the domestic regulation related to TFA.

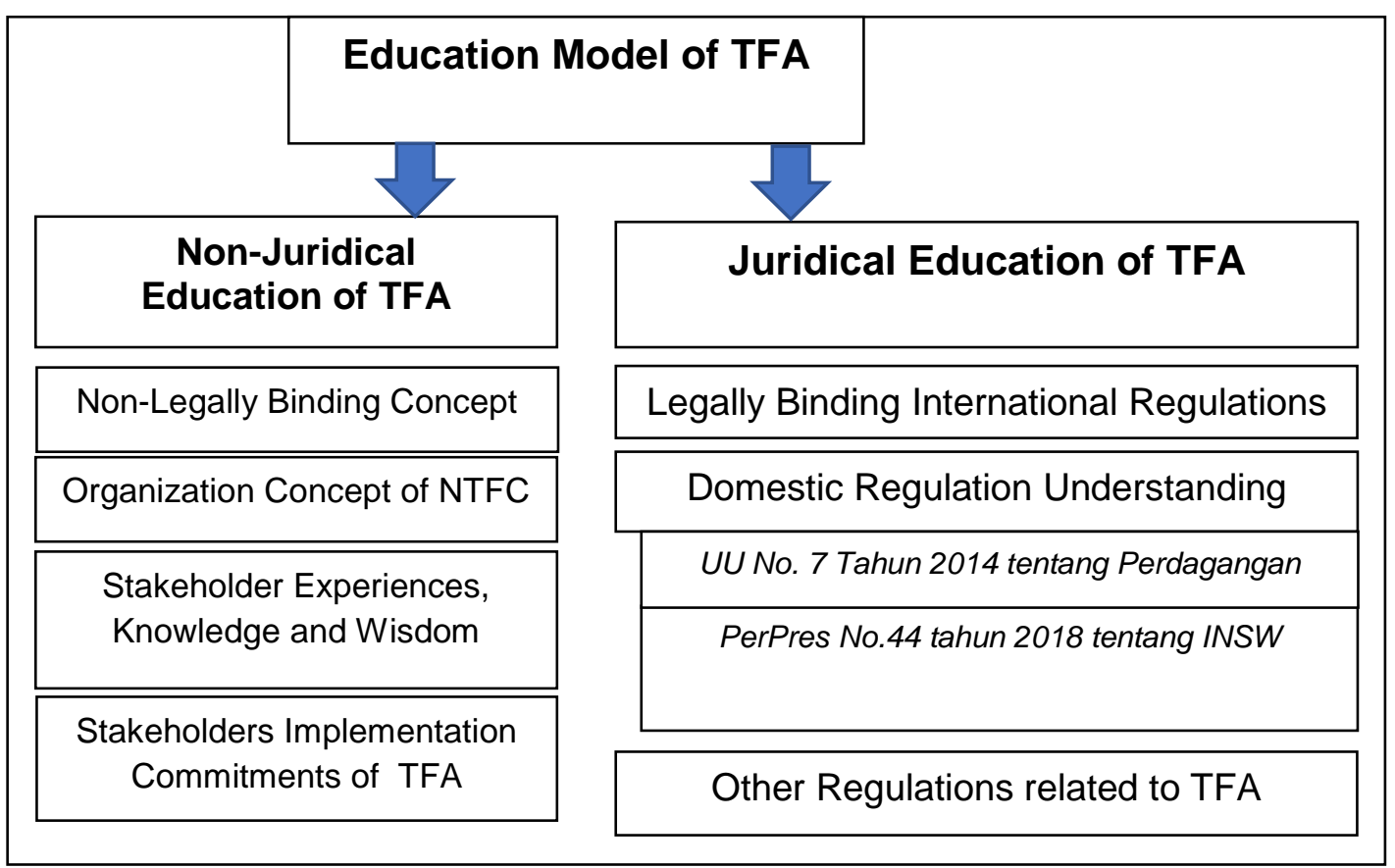

Figure 3. Overview of the Education Model of Trade Facilitation Agreement (TFA) Source: Modified from Jati and Wicaksena (2017) and Researchers Concept (2019) 


\section{RECOMMENDATION}

Based on the descriptive and normative juridical analysis can be seen that there is a room to give more understanding the importance of education about Trade Facilitation Agreement (TFA). It is also important to increase the Indonesian commitment on TFA, so that the stakeholders can get more benefit in WTO and globalizations.

There are two reasons that Indonesia can give more commitments of TFA education model, which are non-juridical education and juridical education elements. The relevant authorities have to give more attention to the domestic regulation understanding related to the full implementation planning of TFA in the year 2022. All stakeholders should support the central government to give more understanding about TFA using specific approach such as Education Model of TFA.

\section{REFERENCES}

APEC. (2017). Capacity Building and Technical Assistance to Implement Programs related to WTO Trade Facilitation Agreement (TFA) Article 1: Publication and Availability of Information. Project Proposal APEC. Retrieved on June 29, 2018 from https://aimp2.apec.org/sites/PDB/Lists/Pr oposals/DispForm.aspx?ID=2145

Arfin, Arif Nugraha. (2016). Analisis Mengenai Lubang-lubang Korupsi di Sektor Bea dan Cukai. Jurnal BPPK Volume 9 Nomor 2, 2016 halaman 123-145, Badan Pendidikan dan Pelatihan Keuangan Kementerian Keuangan Republik Indonesia.

Investindonesia. (2018a). Indonesia Investment and Economic Outlook 2018. Report of Investindonesia. Indonesia Investment Coordinating Board (BKPM). Retrieved on June 18, 2018 from http://www.investindonesia.go.id/images/ uploads/whyinvest_file/Indonesia_Invest ment_and_Economic_Outlook_2018.pdf.

Investindonesia. (2018b). Indonesia Ease of Doing Business 2018. Report of Investindonesia Indonesia Investment Coordinating Board (BKPM). Retrieved on June 18, 2018 from http://www2.investindonesia.go.id/image s/uploads/whyinvest_file/Indonesia_Ease _of_Doing_Business_2018.pdf.
Jati, K. and Wicaksena, B. (2017). Implementation of the Government Regulation Annual Financial Statements of the Company. Prosiding SNaPP: Sosial, Ekonomi dan Humaniora, Jilid 7, terbitan 1, Unisba.

KPMG. (2015). Investing in Indonesia. Working Paper of Klynveld Peat Marwick Goerdeler (KPMG). Retrieved on June 18, 2018 from https://assets.kpmg.com/content/dam/kp mg/pdf/2016/07/id-ksa-investing-inindonesia-2015.pdf.

Laksani, D.D. (2016). Dampak Kerjasama Ekonomi dan Perdagangan IndonesiaYordania dalam Kerangka ASEANJordan Free Trade Area (FTA). Journal of Trade Development and Studies (Cendikia Niaga), Volume $1 \mathrm{No}: 1$, ISSN: 2548-3137.

Muhardi. (2004). Kontribusi Pendidikan dalam Meningkatkan Kualitas Bangsa Indonesia. Mimbar, Volume XX, No.4, Oktober-Desember 2004: 478-492.

NCERT. (2014). Basics in Education: Textbook for B.Ed. Course. National Council of Education Research and Training (NCERT), New Delhi, India. Retrieved on September 16, 2019 from http://www.ncert.nic.in/pdf_files/basic_in_ education.pdf.

OECD. (2018). The Future of Education and Skills: Education 2030. Position Paper, The Organisation for Economic Cooperation and Development (OECD), Retrieved on September 19, 2019 from https://www.oecd.org/education/2030/E2 030\%20Position\%20Paper\%20(05.04.20 18).pdf.

Prabowo, Wahyu. (2013). The WTO Principles and Preferential Trade Agreements: the Case of East-Asia. Working Paper of Asia Europe Institute QXBG6105, Trade and Financial Issue.

Puska KPI. (2014). Analisis Kategorisasi Trade Facilitation Indonesia. Laporan Akhir Analisis Pusat Kebijakan Kerjasama Perdagangan Internasional, Badan Pengkajian dan Pengembangan Kebijakan Perdagangan, Kementerian Perdagangan.

Republik Indonesia. (1985). Undang-undang Nomor 17 Tahun 1985 tentang Pengesahan United Nations Convention on the Law of the Sea (Konvensi Perserikatan Bangsa-bangsa tentang Hukum Laut). Lembaran Negara dan Tambahan Lembaran Negara Tahun 1985. 
Republik Indonesia. (1999). Undang-undang Nomor 28 Tahun 1999 tentang Penyelenggaraan Negara yang Bersih dan Bebas dari Korupsi, Kolusi dan Nepotisme. Lembaran Negara Republik Indonesia Tahun 1999 Nomor 75. Sekretariat Negara RI. Jakarta.

Republik Indonesia. (2008). Act of The Republic of Indonesia Number 14 of 2008 on Public Information Openness. Lembaran Negara Republik Indonesia Tahun 2008 Nomor 61. Sekretariat Negara RI. Jakarta.

Republik Indonesia. (2009). Undang-undang Nomor 49 Tahun 2009 tentang Perubahan Kedua atas Undang-undang Nomor 2 Tahun 1986 tentang Peradilan Umum. Lembaran Negara Republik Indonesia Tahun 2009 Nomor 158. Sekretariat Negara RI. Jakarta.

Republik Indonesia. (2014). Undang-undang No.7 Tahun 2014 tentang Perdagangan. Lembaran Negara Republik Indonesia Tahun 2014 Nomor 45. Sekretariat Negara RI. Jakarta.

Republik Indonesia. (2017). Peraturan Presiden Nomor 91 Tahun 2017 tentang Percepatan Pelaksanaan Berusaha. Lembaran Negara Republik Indonesia Tahun 2017 Nomor 210. Sekretariat Kabinet RI. Jakarta.

Republik Indonesia. (2018). Peraturan Presiden Nomor 44 Tahun 2018 tentang Indonesia National Single Window. Lembaran Negara Republik Indonesia Tahun 2018 Nomor 85. Sekretariat Negara RI. Jakarta.

Ridha, Azman. (2015). Analisa Implementasi Kebijakan Pemerintah (Kemendag) dalam Mensukseskan Agenda Sustainable Development Goals (SDGs). Jurnal Pusdiklat Perdagangan, Volume 1, Nomor 1 Tahun 2015, ISSN: 24773476.

Sauvé, P. (2002). Trade, Education and GATS: What's In, What's Out, What's All the Fuss About?, Working Paper of OECD Centre for Research and Innovation (CERI) Paris, paper for International Conference on Adult Education and Poverty Reduction: A Global Priority, University of Botswana, 14-16 June 2004.

Sitorus, F.H.R.S.A., Priyono, F.J., and Paulus, D.H. (2016). Implementasi Prinsip National Treatment Dalam Sengketa Philippines-Taxes on Distilled Spirits (antara Filipina dengan Uni Eropa). Diponegoro Law Journal, Volume 5, Nomor 4, Tahun 2016.
TPSA. (2018). Session 1-Trade Facilitation at The WTO and in Other Trade Agreements. Working Paper CanadaIndonesia Trade and Private Sector Assistance Project (TPSA).

UNCTAD. (2017). Transport and Trade Facilitation: Series No. 8. Report of United Nations Conference on Trade and Development (UNTACD). Retrieved on June 18, 2018 from http://unctad.org/en/PublicationsLibrary/d tttlb2017d3_en.pdf.

Utami, T. P., and Ridha, A. (2015). Regulatory Impact Assessment Peraturan Impor Produk Tertentu Terhadap Daya Saing Produk Makanan Dalam Negeri. Jurnal Pusdiklat Perdagangan, Volume 1 Nomor 1 Tahun 2015, ISSN: 2477-3476.

Veld, D. W. (2005). Globalisation and Education: What do the trade, investment and migration literatures tell us? Working Paper 254, Overseas Development Institute, London, UK.

WCOOMD. (2018). Doing Business and Its Customs-related Issues: A Study on the Trading Across Borders Indicators May 2018. WCO Research Paper No.44, World Customs Organization (WCO). Retrieved on June 18, 2018 from http://www.wcoomd.org/-

/media/wco/public/global/pdf/topics/resea rch/research-paper-

series/44_doing_business_en.pdf?la=ru$\mathrm{RU}$.

World Bank. (2018). Doing Business 2018: Reforming to Create Jobs. Retrieved on June 18, 2018 from http://www.doingbusiness.org/ /media/W BG/DoingBusiness/Documents/AnnualReports/English/DB2018-Full-Report.pdf.

WTO. (2017). Investing in Skills for Inclusive Trade. Working paper of World Trade Organization (WTO) and International Labour Office (ILO), Retrieved on September 19, 2019 from https://www.wto.org/english/res e/books p e/investinsskills e.pdf.

WTO. (2011). "Chapter 9: Education Policies to Make Globalization More Inclusive", in Education Policies to Make Globalization More Inclusive WTO and ILO Publications, retrieved on September 19, 2019 from https://www.wto.org/english/res e/books p e/glob soc sus e chap9 e.pdf.

Yusuf, S. W. (2015). Pelaksanaan Prinsipprinsip World Trade Organization (WTO) dalam Undang-undang No.7 Tahun 2014 tentang Perdagangan. Skripsi Fakultas Hukum Universitas Hasanuddin. 